\title{
THE ANALYSIS OF VOCABULARY AND LANGUAGE STYLE IN A THOUSAND YEARS SONG BY CHRISTINA PERRI TRANSLITERATED FROM ENGLISH INTO INDONESIAN
}

\author{
Rr. Astri Indriana Octavita \\ English Education Department \\ Faculty of Language and Arts, Indraprasta PGRI University \\ mrs.astriindriana@gmail.com
}

\begin{abstract}
The purposes of this research are: to describe the analysis of vocabulary and the types of language style in A Thousand Years lyric by Christina Perri. The method used in this research is descriptive qualitative in analyzing the data by classyfing them into vocabulary and language style. After analyzing A Thousand Years lyric, the writer can conclude that the vocabulary and the types of language style are classified in eight types. First, simple style, such as Heart beats fast. The second, precious and powerful style which is the name implies such as But watching you stand alone. The third, middle style is a style that is directed to attempt to inflict happy and peaceful atmosphere such as Darling don't be afraid. The fourth, climax is a kind of a style that contains sequences mind that every time the increasing importance of the ideas previously such as Time stands still. Beauty in all she is. The fifth, anticlimax such as I will not let anything take away. The sixth, parallelism is a kind of a style that is trying to achieve alignment in the use of words or phrases which occupied the same function and grammatical form such as every breath. Every hour has come to this. The seventh, antithesis such as I have died everyday waiting for you. And the eight, repetition is the parts of words that are considered important to give the pressure in an appropriate context such as I have loved you for a thousand years.
\end{abstract}

Keywords: Vocabulary, The Language Style, Translation Procedure

\begin{abstract}
ABSTRAK
Tujuan dari penelitian ini adalah: untuk menggambarkan analisis kosakata dan jenis gaya bahasa dalam lirik lagu Thousand Years oleh Christina Perri. Metode yang digunakan dalam penelitian ini adalah deskriptif kualitatif untuk menganalisis data dengan mengklasifikasikanya ke dalam kosa kata dan gaya bahasa. Setelah menganalisis lirik A Thousand Years, penulis dapat menyimpulkan bahwa kosakata dan jenis gaya bahasa diklasifikasikan ke dalam delapan jenis. Pertama, gaya sederhana, seperti jantungku berdebar kencang. Gaya kedua, berharga dan kuat yang namanya seperti namun melihatmu sendirian. Ketiga, gaya tengah adalah gaya yang diarahkan untuk mencoba menimbulkan suasana gembira dan damai seperti kasih jangan takut. Keempat, klimaks adalah semacam gaya yang berisi urutan keberatan bahwa setiap kali semakin penting ide-ide sebelumnya seperti waktu berhenti berputar. Segala tentangnya begitu indah. Kelima, antiklimaks seperti Takkan kubiarkan segalanya berlalu begitu saja. Keenam, paralelisme adalah semacam gaya yang berusaha untuk mencapai keselarasan dalam penggunaan kata atau frasa yang menduduki fungsi yang sama dan bentuk gramatikal seperti Tiap tarikan nafas, Tiap jam telah sampai di sini . Ketujuh, antitesis seperti Tiap hari aku telah mati karena menantimu. Dan delapan, pengulangan adalah bagian dari kata-kata yang dianggap penting untuk memberikan tekanan dalam konteks yang tepat seperti Aku tlah mencintaimu ribuan tahun.
\end{abstract}

Kata Kunci: Kosakata, Gaya Bahasa, Prosedur Penerjemahan 


\section{INTRODUCTION}

Literature is an art form expressed by human thoughts and feelings with the beauty of language, originality of ideas, and the depth of the message. Literature is a social institution that uses language medium. Literature as the creation of the author. A literary genre or type of literature can be grouped into two groups: the imaginative and non-imaginative literature. In practice, nonimaginative literature consists of the works in the form of essays, criticism, biography, autobiography and history. Which include imaginative literature is prose fiction (short story, novella, novel or romance), poetry (epic poetry, lyric poetry and dramatic poetry), and drama (comedy, tragedy, melodrama and drama tragicomedy). The lyrics included in the literary genre because the lyrics are literary works (poems) that contain the outpouring of personal feeling, the wording of a song. So the lyrics together with poetry but presented with a form of singing that is included in the genre of imaginative literature. Language in a literary work is a means of imagination and creativity of the author. The meaning of a literary work can be dug up and searched through the language it uses. Thus, the use of language style on a song includes sounds, a series of sounds, words, strings of words, phrases until the sentence is selected and used carefully. Music is a voice that was structured so that it contains rhythm, song, and harmony particularly sound generated from tools that can generate rhythm. Music can also be called as a very unique phenomenon that can be produced by several musical instruments. Music is also a universal language. All types of expressions can be channeled through music. There are so many benefits that we get from listening to music one of which can stimulate the brain to be calmer in thinking. Based on this, the writer took the research on the analysis of the use of vocabulary and language style in the song lyrics A Thousand Years by Christina Perri popularized the transliterated from English into Indonesian.

This research is interesting because by hearing a song can make the listener feel happy, sad, and somehow fit the theme song and the mood of the listener as well as the lyrics of the song can be used as a lesson. This study is considered attractive because it has not been a lot of research that talks about vocabulary and language style of the song. In addition, because a lot of people who love music or songs. They liked the music ranging from just being a listener to hear and sing the song again. Because listening to songs or singing a song is believed to bring happiness and reduce grief on themselves. Therefore, the writer takes the subject of research on the analysis of the vocabulary and style of language in the song lyrics A Thousand Years Christina Perri is transliterated from English into Indonesian. The research also considered important because finding a new theory of language transliteration style lyrics that style tonal language like the simple style, the style of the precious and powerful language, and style of middle. Other new theory is the style language based on sentence structure as climax, anticlimax, parallelism, antithesis and repetition. Quoted from ulongfirdausfauzy.blogspot.co.id/2013/06/gaya-bahasa_3548.html can be explained a variety of styles the following languages: English various styles can be seen by: (1) Language style by tone. Language style based on a suggestion by the tone emitted from a series of words contained in a discourse. Often this suggestion will be more obvious if the suggestion was followed by a letter from the speaker, when the grain is facing is the spoken language. With this background, style of angle contained tone of discourse, divided into: a simple style, the style of the precious and powerful, as well as middle style. A. Simple Style. This style is usually suitable to give instructions, orders, lessons, lectures and the like. Therefore, to use this style effectively, writers should have enough skill and knowledge. B. Language style of precious and Powerful. As the 
name implies, this style is full of vitality and energy, and is usually used to drive something. Stir something not just with energy and vitality use speaker, but also can use the tone of grandeur and glory. C. Style of Middle. Middle style is a style that is directed to attempt to inflict happy and peaceful atmosphere. Because the goal is to create happy and peaceful atmosphere, the tone also is gentle, affectionate and contain healthy humor. D. Style Language Based Sentence Structure. Style language based on sentence structure composed of a variety of stylistic. Style language based on sentence structure includes: 1. Climax. Stylistic climax is a kind of a style that contains sequences mind that every time the increasing importance of the ideas previously. Example: Misery produce patience, patience experience, and experience hope. 2. Anticlimactic. Anticlimax language style is a style that is a reference whose ideas are sorted from the most important successive idea less important. Example: the construction of five years has been launched simultaneously in the capital city, the capital of the province, county, district, and all villages throughout Indonesia. 3. Parallelism is a kind of a style that is trying to achieve alignment in the use of words or phrases which occupied the same function in the same grammatical form. Example: not only act that should be condemned, but also must be eradicated. 4. The antithesis is a style that contain ideas contrary to the use of words or groups of words opposite. Example: He often refused, but yet never hurt. 5. Repetition. Repetition is the repetition of sounds, syllables, words or parts of words that are considered important to give the pressure in an appropriate context. Example: Or would you go with the insects land, go with the roaches, go with them that infiltrate the soil, infiltrating nature.

The method is defined as a rule, it contains things that are systematic. The method was created for the purpose of guidance. The research method is a scientific way to obtain data and information for specific purposes that are rational, empirical and systematic. The method used in this research is descriptive qualitative method. Here is an explanation of the method of qualitative research. Semi (2012: 28) says, "Research methods of Qualitative research methods with an emphasis on figures, but give priority to the depth of the understanding of the interaction between the concepts being studied empirically." Meanwhile, Parkinson and Drislane (2011), says "qualitative research is research using methods such as participant observation or case studies roommates result in a narrative, descriptive account of a setting or practice." this statement explains that the method of qualitative research is an information search is done by studying and doing note against individual behavior and conduct an analysis of the data as a case to be investigated. In other words, qualitative methods conducted on a particular object gain firsthand experience as a source and research results. Research done by exploring the problem of individual behavior in the objects of research. Note data obtained as a result of this research will be statements and a more detailed description of the problem. Meanwhile, the statement said Drislane Parkinson and qualitative research can be done through observation and study each case. The conclusion from this research is a narrative as information and reports in the form of drawings and descriptions are described in depth. The approach used in this research methodology is a social approach. Declared a social approach for song A Thousand Years Christina Perri meaningful to the lives of humans as social beings who love each other and love. As we know that human beings cannot live alone without dealing with humans or other creatures even for any small business. Adoption of the opinion that the social Dominelli an integral part of a human relationship that requires a proclamation on the things that are fragile in it. Research using social approach is a process of expressing a logical, systematic and methodical social phenomena implied lyrics of the song A Thousand Years to express the benefit of society and 
science. Research as a scientific activity carried out continuously to reveal the real truth of the object under study. Social approach used by the authors to focus its research is to read, understand and analyze any implied meaning of the lyrics of the song A Thousand Years were popularized by Christina Perri and on a transliteration of the English language.

In this research, the writer uses several steps to analyze the data. The author will use data analysis techniques to examine a song by listening to the song over and over again, to understand the words and describe the content of the study. Here are some steps as mentioned author. 1. Data Collection. In this step, the authors collected data from various sources related vocabulary, style, and transliteration. Prior to determining the purpose of research, the authors conducted a search for a song you like writer and have educational value and high social element, which then leads to the selection of songs popularized A Thousand Years by Christina Perri. The next step is to listen to and understand the lyrics of the song with the purpose of appreciating that the authors understand the content, significance, and and the message it conveys. 2. Data Classification. In classifying the data, the authors quantify and categorize the data collected in the previous process. This phase is intended to simplify and speed up the analysis process so that the data will be more orderly and systematic. Furthermore, the authors do a lot more research to find sources on the internet. In addition, with several books to obtain data or information about the theories contained in the study. 3. Data Analysis. In analyzing the data which aims to determine the data directly related to the lyrics of the song and vice versa. Furthermore, the authors analyze the lyrics to facilitate the listener with the form description. 4. Determination of Conclusion. The final step in this research is to determine conclusions. In this step the authors note back all the results from the very first step to end adapted to song lyrics. In order for this research is more suggestive and directional, it is necessary to determine the focus and sub focus research. The focus of this research is the vocabulary used, style and type-type, as well as one of the transliteration of the translation process in the analysis of the vocabulary and style of language in the lyrics of the song A Thousand Years popularized by Christina Perri is transliterated from English. Thus, this study is the sub focus song A Thousand Years popularized by Christina Perri and transliterated from English into Indonesian.

The research instrument used in this research are: 1. Researcher or Writer itself, because the data collection activities cannot be done by proxy or other means. 2 . The data obtained from the lyrics of the song A Thousand Years by Christina Perri popularized the transliterated from English to Indonesian and be analyzed through a social approach in the analysis of the vocabulary and style. 3. A Thousand Years lyrics are transliterated from English into Indonesian. 4. Based on the description of the findings of the study, the analysis of the vocabulary and style of language in the song lyrics A Thousand Years - Christina Perri is transliterated from English when examined from a style based on the tone and sentence structure. The steps of recording data on the author to determine the style of the language in the analysis of the vocabulary and style of language in the lyrics of the song A Thousand Years popularized by Christina Perri transliterated from English are as follows: Listen to and understand the lyrics of the song A Thousand Years popularized by Christina Perri is transliterated from English repeatedly to obtain the value that will be studied is the language style and the types. Collect and compile the data written in the form of theories experts obtained from books and internet sources. Penning the lyrics of the song A Thousand Years - Christina Perri in English and Indonesian. Analyzing return vocabulary and language style in the song lyrics A Thousand Years - Christina Perri is transliterated from English in the analysis of the vocabulary and style. Make a final conclusion 
concerning the presentation style of language in the lyrics of the song A Thousand Years Christina Perri is transliterated from English in the analysis of the vocabulary and style. Recently compiled research in the form of articles for journaled.

\section{DISCUSSION}

\section{SONG LYRIC: $A$ Thousand Years dalam Bahasa Inggris}

Lirik lagu: A Thousand Years - Christina Perri

Heart beats fast

Colors and promises

How to be brave

How can I love when I'm afraid to fall

But watching you stand alone

All of my doubt suddenly goes away somehow

One step closer

[Chorus:]

I have died everyday waiting for you

Darling don't be afraid I have loved you

For a thousand years

I'll love you for a thousand more

Time stands still

Beauty in all she is

I will be brave

I will not let anything take away

What's standing in front of me

Every breath

Every hour has come to this

One step closer

[Chorus:]

I have died everyday waiting for you

Darling don't be afraid I have loved you

For a thousand years

I'll love you for a thousand more

And all along I believed I would find you

Time has brought your heart to me

I have loved you for a thousand years

I'll love you for a thousand more

One step closer

One step closer

[Chorus:]

I have died everyday waiting for you

Darling don't be afraid I have loved you

For a thousand years

I'll love you for a thousand more

And all along I believed I would find you

Time has brought your heart to me 
I have loved you for a thousand years

I'll love you for a thousand more

\section{TRANSLITERATED FROM ENGLISH INTO INDONESIAN}

Jantungku berdebar kencang

Warna-warni dan janji-janji

Bagaimana agar berani

Bagaimana bisa aku cinta saat aku takut jatuh?

Namun melihatmu sendirian

Segala bimbangku mendadak hilang

Selangkah lebih dekat

\section{CHORUS}

Tiap hari aku telah mati karena menantimu

Kasih jangan takut

Aku telah mencintaimu ribuan tahun

Aku kan mencintaimu ribuan tahun lagi

Waktu berhenti berputar

Segala tentangnya begitu indah

Aku akan berani

Takkan kubiarkan segalanya berlalu begitu saja

Apa yang menghalangi di depanku

Tiap tarikan nafas

Tiap jam telah sampai di sini

Selangkah lebih dekat

CHORUS

Tiap hari aku telah mati karena menantimu

Kasih jangan takut

Aku tlah mencintaimu ribuan tahun

Aku kan mencintaimu ribuan tahun lagi

Dan selama itu aku yakin aku kan temukan dirimu

Waktu tlah membawa hatimu padaku

Aku tlah mencintaimu ribuan tahun

Aku kan mencintaimu ribuan tahun lagi

Selangkah lebih dekat

Selangkah lebih dekat

Based on the description of the research findings are as follows:

1. The language style by Tone and three types are:

a. Simple style

Learn about two people falling in love

Heart beats fast

Colors and promises

How to be brave

How can I love when I'm afraid to fall

Jantungku berdebar kencang

Warna-warni dan janji-janji 
Discussion :

Bagaimana agar berani

Bagaimana bisa aku cinta saat aku takut jatuh?

Lyrics quote above are the lyrics of the beginning of the song A Thousand Years. If told meaning into Indonesian is the story of two people falling in love, the lovers a different world, one human and one vampire. The two people fell in love when signs such as heart palpitations, increasingly hollow words of their soul, but they do not dare to reveal feelings for each other, because they are afraid to feel heart broken again. This suggests that these symptoms feelings of people who are in love. Because the lyrics using simple language style that is typically used to provide a good picture of feelings of love and sorrow, and the like. Although not directly conveyed by the words that is standard but can be drawn lessons from the meaning of the word implied.

\section{a. Language style of Precious and Powerful}

Invites listeners who are in love to dare to open on your own feelings so that a sense of wavering in missing hearts into deep belief

But watching you stand alone

All of my doubt suddenly goes away somehow

One step closer

Namun melihatmu sendirian

Segala bimbangku mendadak hilang

Discussion :

Selangkah lebih dekat

The above quote lyrics invite us (the audience) who are in love to dare to open on your own feelings so that a sense of wavering in missing hearts into deep conviction. This happens because the lyrics above contains Language Style of Precious and Powerful. As the name implies, this style is full of vitality and energy. Typically used to drive or push something. Stir something not just by using the power and vitality of the speaker, but also can use the tone of grandeur in the form of words, vision, or the feelings of the human being and kemulyaan. Fragment lyrics as invites listeners to continue to be in addition to those we love, do not ever leave him. So as to see it for yourself, we can feel the turmoil and indecision perceived as gone and lost because of its presence.

b. Middle style

Their promise to faithfully support, cherish and love forever until thousands of years to come

I have died everyday waiting for you

Darling don't be afraid I have loved you

For a thousand years

I'll love you for a thousand more

Tiap hari aku telah mati karena menantimu

Kasih jangan takut

Aku tlah mencintaimu ribuan tahun

Aku kan mencintaimu ribuan tahun lagi

Discussion: 
Quote song lyrics on top of a sentence loyalty. The words that cause the sacrifice of love. This quote by Style Language lyrics by Nada namely Middle style. Middle style is a style that is directed to the effort to create an atmosphere of sacrifice and loyalty. Because the goal is to create a peaceful mood, the tone also is gentle, affectionate and contain commitments. That attract listeners who are in love or falling in love and the song is often heard by the public.

2. Language style based on Sentence Structure along with five types are in the analysis of the vocabulary and style:

a. Climax

Describing a state based on the sequence

Time stands still

Beauty in all she is

Waktu berhenti berputar

Segala tentangnya begitu indah

Discussion:

The lyrics above can be categorized as a style language based Sentence Structure is the climax. A kind of a style that contains sequences of time and thought that every time the increasing importance of the ideas previously. Example: time stops, misery led to patience, patience experience, and experience the beauty of hope. If you understood the meaning of the lyrics of the song, he tells a series of events have sequentially and orderly.

\section{b. Anti climax}

Listeners know the intent conveyed is unyielding to any

I will be brave

I will not let anything take away

What's standing in front of me

Aku akan berani

Takkan kubiarkan segalanya berlalu begitu saja

Apa yang menghalangi di depanku

Discussion:

The lyrics above mean to let you know that there are unyielding nature. Courage to defend his love though different world had set fire to their love, remained unyielding and maintain her love despite steep storm hit, will never be extinguished feelings. The language style is the style language based Sentence Structure - anticlimactic. The language style is a style that refers to the ideas of the most important sorted consecutive kegagasan less important. For example: he would still dare, will not be allowed to pass everything, anything that prevented though. So that the wording of this listener can easily know the meaning of the lyrics.

\section{c. Parallelism}

Prayer for the lover in every moment

Every breath

Every hour has come to this

One step closer

Tiap tarikan nafas 
Tiap jam telah sampai di sini

Selangkah lebih dekat

Discussion :

Quote song lyrics on top of the same grammatical form to convey the intended meaning. This is explained by Style Language Sentence Structure is based parallelism. Parallelism is a kind of style that seeks to achieve equality in the use of words or phrases which occupied the same function in the same grammatical form. Example: on the sidelines pull breath of seconds, minutes to hours she always prayed for his beloved idol.

\section{d. Antithesis}

Presenting the words to the contrary or opposite

I have died everyday waiting for you

Darling don't be afraid I have loved you

For a thousand years

I'll love you for a thousand more

Tiap hari aku telah mati karena menantimu

Kasih jangan takut

Aku tlah mencintaimu ribuan tahun

Aku kan mencintaimu ribuan tahun lagi

Discussion:

Christina Perri tell us that the expression statement every day I had died waiting for a metaphor only, no human being none in the era of today who are willing to die stupid just for the sake of her lover, so contrary to the meaning of the lyrics of a song that is so mendayuh as if ready to die for the sake of his beloved idol. Quote the lyrics of this meticulous with Style Language based Sentence Structure is antithesis. Note The antithesis is a style that contains ideas that are contrary to use words or groups of words opposite. Example: every day I had died waiting for you despite the fact that he may not die and was still waiting bias.

\section{e. Repetition}

Repetition of rhythmic sound that contains deep meaning And all along I believed I would find you

Time has brought your heart to me

I have loved you for a thousand years

I'll love you for a thousand more

One step closer

One step closer

Dan selama itu aku yakin aku kan temukan dirimu

Waktu tlah membawa hatimu padaku

Aku tlah mencintaimu ribuan tahun

Aku kan mencintaimu ribuan tahun lagi

Selangkah lebih dekat

Selangkah lebih dekat

Discussion:

Most of the lyrics made repetition sounds and rhythmic so attractive and get the deepest meaning. Moreover, that is easy to understand. Listeners can understand the lyrics just a few times listening to relax and enjoy every tune that was created to 
accompany the song. Lyrics are examined by Style Language Sentence Structure is based on repetition. Repetition is the repetition of sounds, syllables, words or parts of words that are considered important to give the pressure in an appropriate context. Syllables are selected to serve as the lyrics were not arbitrary. Selected based on words that can be adjusted to the tone and made repeated so memorable. For example in words like: I believe I have found you right, time will tell, as I have loved you, love thousands of years, then one step closer and closer.

\section{Pie Chart 1.1}

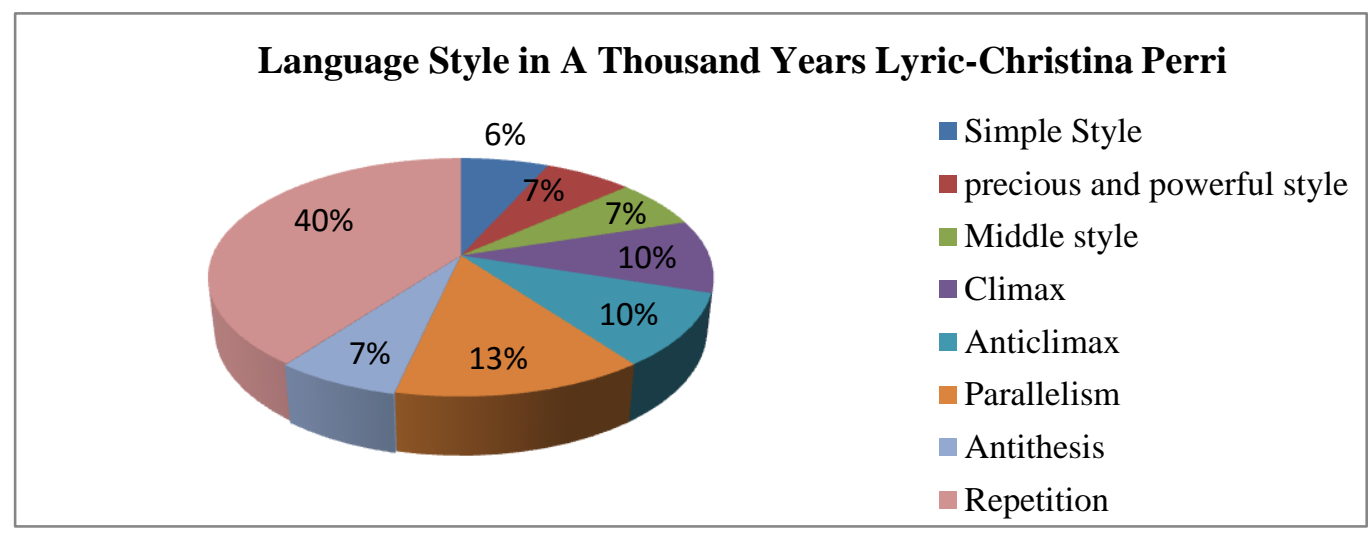

\section{CONCLUSION}

After reading the whole content writing, the writer can draw some conclusions contained as follows:

1. Analysis of the vocabulary in the song A Thousand Years - Christina Perri described in Style of Language Sentence Structure by getting the dominant type of repetition that is as much as $39.8 \%$. Style language based on the structure of the sentence (reps) a repetition of sounds, syllables, words or parts of words that are considered important to give the pressure in an appropriate context. All the lyrics definitely use this language in the style of lyric writing. It intends to emphasize to the audience the meaning of the lyrics of the song which is a means of delivering the intent of the songwriter who are in love. Not only lyric that experienced repetition of sounds but adapted well to tone or music is so easy to understand and beautiful to hear. Can be quoted from the lyrics of this song (I have died everyday waiting for you, Darling don't be afraid I have loved you, For a thousand years, I'll love you for a thousand more. And all along I believed I would find you. Time has brought your heart to me. I have loved you for a thousand years. I'll love you for a thousand more. One step closer. One step closer) visible word repetition sound experience and certainly the sentence that experienced repetition of sound in a song lyric is in part reff atau chorus.

2. Types of style in this song is a style based on the tone and style of the language based on the structure of the sentence. Style tonal language, there are three types: simple style, the style of precious and powerful language, and style of the middle with the acquisition of the results of each analysis as much as $6.7 \%$. Simple style that aims to provide lessons can be taken from 
the lyrics (Heart beats fast. Colors and promises. How to be brave. How can I love when I'm afraid to fall) teach his audience about the feeling of falling in love and freedom of expression. precious and powerful style of language as well as $6.7 \%$ is used to drive something. Something in this case the intended audience. So when listening to this song the listener moved the hearts, minds and intention to help others even if only small things with delivery using a tone of grandeur, glory, full of energy and vitality as the quote lyrics (But watching you stand alone. All of my doubt suddenly goes away somehow. One step closer). Middle style is a style geared to businesses to foster a sense of loyalty as the quote lyrics ( $I$ have died everyday waiting for you. Darling don't be afraid I have loved you. For a thousand years. I'll love you for a thousand more) convincing that creating a peaceful mood, the tone also is gentle, affectionate and contain commitments. That attract listeners who are in love or falling in love and the song is often heard by the public. In addition to the language style is based on the tone, the authors also found a style based on the structure of a sentence consisting of five types of climax, anticlimax, paraleisme, antithesis, and reps. Based on the five types of language styles based on the structure of the sentence that gets results is dominant as many reps as $39.8 \%$. repetition is the repetition of sounds, syllables, words or parts of words that are considered important to give the pressure in an appropriate context. As we know that all the songs have a sound or a word or phrase that is repeated to emphasize the true meaning of the song as the lyrics to this song (And all along I believed I would find you. Time has brought your heart to me. I have loved you for a thousand years. I'll love you for a thousand more. One step closer. One step closer) explains that this song is repetition sounds, syllables, words or parts of words that are considered important to give the pressure in an appropriate context. Syllables are selected to serve as the lyrics were not arbitrary. Selected based on words that can be adjusted to the tone and made repeated so memorable. The climax containing sequences mind that every time the increasing importance of the idea previously contained only $9.9 \%$ in the lyrics and can be cited (Time stands still. Beauty in all she is). Anticlimax is a stylistic of reference whose ideas are sorted from the most important successive kegagasan less important or from the particular to the general idea contained $9.9 \%$ in the lyrics of this song. As the quote from the song lyrics (I will be brave. I will not let anything take away. What's standing in front of me). Parallelism sort of style that seeks to achieve equality in the use of words or phrases with similar functions in the same grammatical form contained $13.6 \%$ in the lyrics of this song is based on a quote lyrics (Every breath. Every hour has come to this. One step closer). The antithesis contains ideas that are contrary to the use of words or word groups studied opposite result amounted to $6.7 \%$ of the lyrics (I have died everyday waiting for you. Darling don't be afraid I have loved you. For a thousand years. I'll love you for a thousand more) contain the opposite but it gives meaning and use of the same word groups.

If understanding the meaning of the lyrics in A Thousand Years - Christina Perri, a lot of lessons about love and love each other that can be taken. Humans by nature always love the opposite sex, you should choose a spouse who can make it comfortable and unseen. The sacrifice of love would die for a couple is good, but when is not suitable to be implemented in the current globalization era, naturally love and love for your Lord. So if we lose a loved one, then the pain will not last long because we know that God is always with us. 


\section{REFERENCES}

Aminuddin. 2004. Dalam https://ulongfirdausfauzy.blogspot.co.id/2013/06/gayabahasa_3548.html. Pengantar Apresiasi Karya Sastra (diakses pada 12 Juni 2015 pukul 01.25 WIB).

Fananie, Z. 2000. Telaah Sastra. Surakarta: Muhammadiyah University Press.

Finoza, Lamuddin. 2008. Dalam ulongfirdausfauzy.blogspot.co.id/2013/07/gayabahasa_3549.html. Komposisi Bahasa Indonesia (diakses pada 12 Juni 2015 pukul $01.25 \mathrm{WIB})$.

Kazunari, Temi. 2014. Dalam http://lantunanilmuku.blogspot.co.id/2014/03/terjemahan-danlirik-lagu-thousand.html (diakses pada 11 Januari 2016 pukul 19.00).

Letto. 2012. Dalam http://kumpulanarsipsaya.blogspot.com/2012/04/analisis-gaya-bahasa-liriklagu-letto.html\# (diakses pada 20 Januari 2016 pukul 15.00).

Najid, Moh. 2003. Mengenal Apresiasi Prosa Fiksi. Surabaya: University Press dengan Kreasi Media Promo.

Simanungkalit, Arthur. 2015. Dalam http://www.wowkeren.com/lirik/lagu/christina_perri/athousand-years.html (diakses pada 21 Januari 2016 pukul 15.3).

Suharjati, Florentina dan Supeno. 2014. Translation. Jakarta: Unindra Press. 